\title{
Impact of the Human Activities on the Local Climate and Environment of the Suez City in Egypt
}

\author{
Mona Fouad Kaiser \\ Geology Department, Faculty of Science, Suez Canal University, Ismailia, Egypt \\ Email: $\underline{\text { monakaiser2013@gmail.com }}$
}

Received 9 April 2014; revised 6 May 2014; accepted 2 June 2014

Copyright (C) 2014 by author and Scientific Research Publishing Inc.

This work is licensed under the Creative Commons Attribution International License (CC BY).

http://creativecommons.org/licenses/by/4.0/

(c) (i) Open Access

\begin{abstract}
Surface temperature and vegetation are the major land cover changes that significantly affect on the thermal environment. In the present study, remote sensing techniques were applied to identify the relationship between anthropogenic activities and the thermal environment in the North Gulf of Suez area. Results have indicated that the urbanization and agricultural expansion have been increased during the last 25 years. Although urban areas increased from $49 \mathrm{~km}^{2}$ in 1987 to $57 \mathrm{~km}^{2}$ in 2012, the urban heat island-range declined from very high and high, to moderate and low. An expansion in cultivated areas from $3 \mathrm{~km}^{2}$ in 1987 to $26 \mathrm{~km}^{2}$ in 2012 was responsible for the decline. The results of this study provided valuable information for understanding the local thermal changes that associate rapid urbanization and expansion of cultivated areas. Consequently, this work recommends that proper planning and management regimes for land use and cover changes associated with rapid urbanization will result in positive impacts on the local climate and environment.
\end{abstract}

\section{Keywords}

Urban Heat Island, Urbanization, Vegetation Expansion, North Gulf of Suez, Image Classification

\section{Introduction}

Human activities during different civilizations have long been known to be categorized in either urbanization or cultivation. Urbanization has been and remains a major form of land use and land cover changes in human history [1]. The replacement of vegetation-cover by an urban highly impervious landscape, such as asphalts, concrete, and building rooftops prevents precipitation to penetrate soils. Urbanized areas usually exhibit high ther- 
mal conductivity and radiation heat budgets, characterized by increased atmospheric and surface temperatures when compared to the surrounding rural areas [2]. Urban materials, including construction materials, roofs, asphalt, concrete, metals, and roads absorb more heat from the sun. The subsequent energy release causes urban areas to be warmer than the surrounding non-urban areas, giving rise to the urban heat effect [3]. Therefore, the temperature difference between urban and rural areas contributes to the development of the Urban Heat Island (UHI). UHI quantitatively describes the increased temperature of either the urban surface, or the urban atmosphere compared to rural surroundings due to increased anthropogenic activities or the consequences of human activities. [4] emphasized a number of factors associated with UHI intensity, including building density [5], industrial areas [6], impervious surface fraction [7], population concentration [8], and road density [9].

Remote sensing and geographic information system (GIS) techniques are powerful and effective tools widely applied in detecting the spatio-temporal dynamics of land use cover changes. [10] integrated remote sensing and GIS to study the urban thermal environment in Guangzhou. Normalized Difference Build-up Index (NDBI), and Normalized Difference Vegetation Index (NDVI) were used to qualitatively evaluate the relationship between LST and land use/land cover (LULC). The results indicated that most urban developed regions were located in high LST areas. LST is commonly increased with the density of urban development and bare land, but decreased with vegetation cover [10]. Remote sensing data provide a continuous and synchronized portrayal of urban surface temperature spatial patterns [11]. [12] applied remote sensing technology and spatial/multivariate statistics methods to examine the impacts of rapid urbanization on the urban thermal environment of Guangzhou, South China. The results indicated that urbanization in Guangzhou had a substantial effect on the regional thermal environment, with notable UHIs during 1990-2009. Mean temperatures were higher in urban areas than in the surrounding suburban/rural areas over the entire period. High temperature anomalies were closely associated with developed land, and heavily industrialized districts. Satellite-derived land surface temperatures (LSTs), obtained from satellite thermal infrared (TIR) imagery [13], were employed to characterize UHI phenomenon [11]. The approach is positively related with (NDBI), and negatively with (NDVI).

The objectives of this study were to understand and analyze the local changes in thermal environment that occurred during a period of twenty-five years (1987-2012) in the northern parts of the Gulf of Suez. The region has been experiencing a rapid expansion in urban development, and vegetation cover over the last 25 years.

\section{Data}

\subsection{Study Area}

The Gulf of Suez basin is a northwest-elongated depression separating Sinai massif from the Eastern Desert-Red Sea hills. It is a topographic sink within the stable shelf of Egypt which is characterized by intensive block faulting and massive accumulation of sediments [14]. The sedimentary succession of the Gulf of Suez is generally thick one, ranges in age from Carboniferous to Recent and non-conformably overlying the basement rocks. The geologic and tectonic setting of the study area is inherited due to the regional tectonic framework of the Gulf of Suez and Red Sea rift.

The Suez Governorate is one of the fame Suez Canal Region's urban governorates. It is located at the northern tip of the Gulf of Suez, where the Suez Canal leads forward into the north (Figure 1). The Suez Governorate occupies a total surface area of $\sim 9000 \mathrm{~km}^{2}$. The area is bounded by Gabal Ataqa to the west and Suez Canal to the east.

The Suez Governorate infrastructure is supported by investments in wide network of internal and transportation roads, energy-generation stations, companies of drinking and sewage water, mature industrial zones, economic free-zone, international harbours, etc. Furthermore, the Suez Governorate supports many investment industries, including petroleum, foods, basic chemicals and chemical products, basic metallic, and engineering and electronic industries.

The Suez Governorate is divided into four administrative districts; The Suez City, Ataqa, Al-Ganayen, and Al-Arbaeen Districts. Ataqa District is a heavily industrial zone. Al-Ganayen District is a primarily zone of dense fruit cultivated lands. The Suez City is a growing industrial and commercial zone due to the presence of natural resources, including mineral and rock raw materials, ready-cultivated lands, growing fisheries, and scenery-touristic sites. Moreover, the Suez City centralizes most governmental commercial and economic bureaus and agencies. Al-Arbaeen District is a heavily populated urban area with many variable civilian activities. 


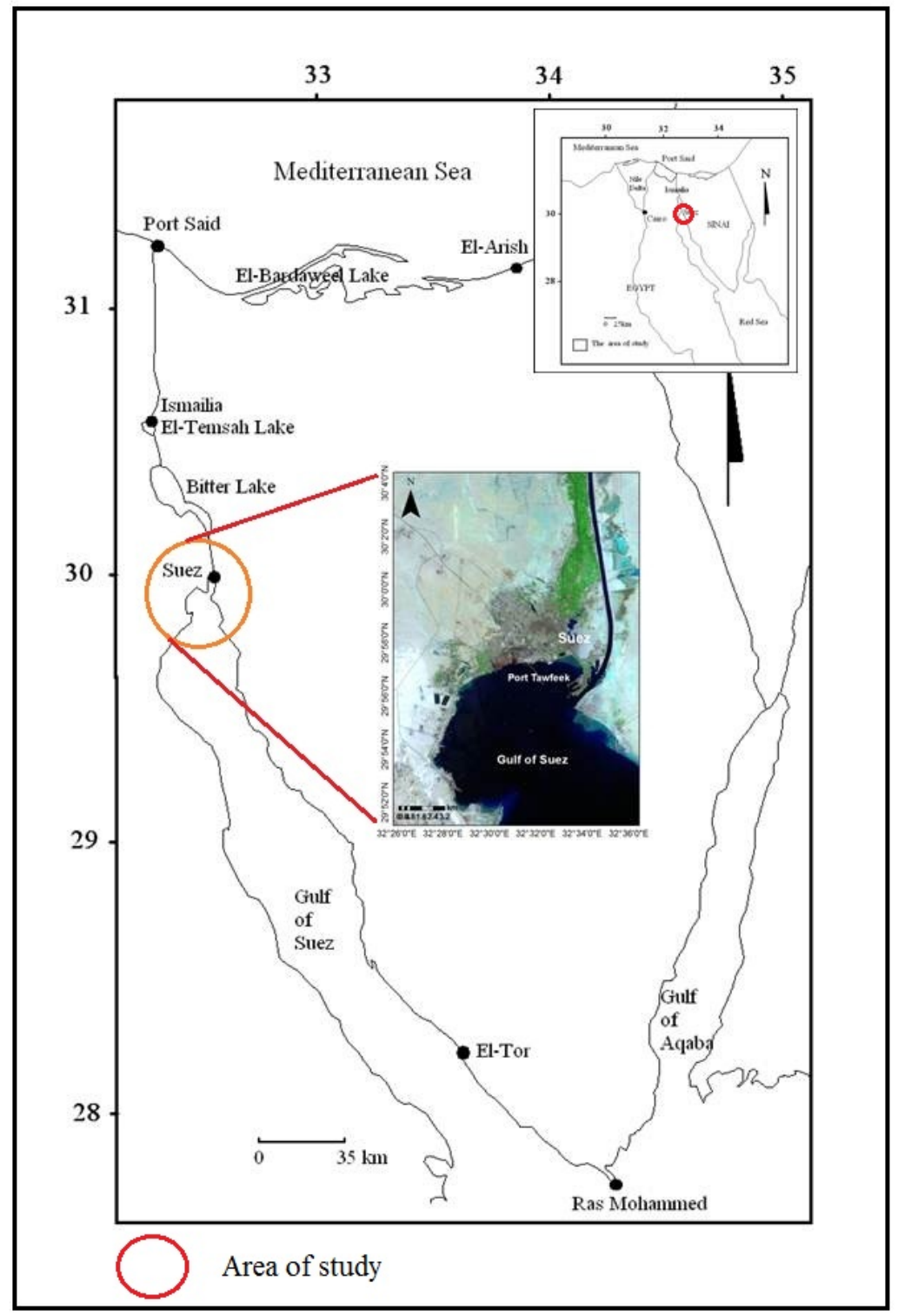

Figure 1. Area of study.

\subsection{Satellite Data}

The satellite remote sensing provides a straightforward and consistent approach to determine the Urban Heat Island (UHI), expressing the thermal difference between urban and rural areas. In this study, the remote sensing images were used to recognize the relationship between the urban heat islands (UHI), and the land use changes during the time span extending from 1987 to 2012. Three sets of the remotely-sensed data were acquired; Landsat5 Thematic Mapper (TM) in 1987, and Enhanced Landsat Thematic Mapper Images Plus (ETM+) in 2000 and 2012 (Table 1). Using 3 remote sensing datasets are adequate during 1987-2012 to monitor significant LULC changes in the study site.

\section{Methods and Image Processing}

Two measuring methods are used to compute LST. These include 1) direct ground recorded LST, and 2) satellite-retrieved LST. The satellite-retrieved LST data have better advantages when compared to the ground measurements due to their high spatial resolution, extensive coverage area, and less time-consuming data retrieval. 
Table 1. Landsat TM and ETM+ satellite images data.

\begin{tabular}{ccc}
\hline Data & Resolution $(\mathrm{m})$ & Date \\
\hline Landsat5 TM & 120 & 20 August 1987 \\
Landsat7 ETM+ & 30 & 23 September 2000 \\
Landsat7 ETM+ & 30 & 22 August 2012 \\
\hline
\end{tabular}

Generally, the remotely-sensed thermal imagery provides the potential to improve our understanding of urban surface energy budgets, and observe UHI effects. Thermal imagery generates a time-synchronized dense temperature data grid, and distinctive temperatures for individual buildings [10]. Thermal infrared information from satellites can be converted to brightness temperature using Planck's law to measure surface temperatures [15].

In the present study, the remote sensing image processing techniques were applied to classify land cover, and extract the UHIs in the North Gulf of Suez area during the period extending from 1987 to 2012.

\subsection{Classification of Land Use and Land Cover}

Image classification is used to automatically categorize all pixels in an image into land cover classes or themes. Unsupervised classification was performed separately on the three sets of remotely-sensed images (Table 1) using a histogram peak cluster technique to identify dense or frequently occurring pixelated areas [16]-[20]. In the unsupervised approach, spectrally separable classes are determined to form a supervised classification scheme. ENVI 4.8 was used to process satellite image classifications. [21] applied supervised maximum likelihood classification (MLC) to detect land cover classes. Once a sufficient number of the spectral subclasses were obtained for all information classes, a maximum likelihood classification was performed with the full set of refined spectral classes [19]. MLC is a statistically complex approach to classify images for change detection; however several studies reported that the methodology is most effective for supervised classification [22] [23]. Supervised classification was verified for each year using field investigation information collected from more than 25 ground checkpoints.

\subsection{Calculation of Urban Heat Islands (UHIs)}

Urban areas represent a complex mix of different land cover types and materials, including developed and vegetated areas, soil surfaces, and water bodies. Satellite sensors record earth's surface image from the radiance value, which depends on land cover spectral characteristics. UHIs were retrieved from the study area using ENVI 4.8 and ERDAS Imagine 9.3 as follows.

\subsubsection{Digital Number (DN) Values to Spectral Radiance Conversion}

Landsat calibration equation [24] was used to convert the Landsat TM/ETM+ thermal infrared (TIR) band, low gain, $(10.44-12.42 \mu \mathrm{m})$ digital number $(\mathrm{DN})$ to spectral radiance in units $\left(\mathrm{W} \cdot \mathrm{m}^{-2} \cdot \mu \mathrm{m}^{-1} \cdot \mathrm{sr}^{-1}\right)$. All specific calibration coefficients, and related parameters, including sun elevation, gain and offset were extracted from a level 1 product header or ancillary data record.

\subsubsection{Spectral Radiance to Effective At-Sensor Brightness Temperature Conversion}

Spectral radiance was converted to the at-satellite brightness temperature (i.e. blackbody temperature) using Equation (1), [24] [25]. The $K_{1}$ and $K_{2}$ constant values for Landsat5 TM and Landsat7 ETM+ are shown in Table 2:

$$
T_{i}=\frac{K_{2}}{\ln \left(\frac{K_{1}}{L_{\lambda}}+1\right)}
$$

where:

$T_{i}$ : effective at-satellite brightness temperature in Kelvin;

$K_{1}$ : calibration constant 1 in $\mathrm{W} /\left(\mathrm{m}^{2} \cdot \mathrm{sr} \cdot \mu \mathrm{m}\right)$; 
Table 2. TM thermal band calibration constant.

\begin{tabular}{ccc}
\hline Units & $\mathbf{W} /\left(\mathbf{m}^{2} \cdot \mathbf{s r} \cdot \boldsymbol{\mu m}\right)$ & Kelvin \\
\hline Constant & $K_{1}$ & $K_{2}$ \\
Landsat7 ETM+ & 666.09 & 1282.71 \\
Landsat5 TM & 607.76 & 1260.56 \\
\hline
\end{tabular}

$K_{2}$ : calibration constant 2 in Kelvin;

$L_{\lambda}$ : spectral radiance at the sensor's aperture.

\subsubsection{Effective At-Sensor Brightness Temperature to LST Conversion}

LST can be extracted using Equation (2), [12] and [4]:

$$
T_{s}=\frac{T_{i}}{1+\left(\lambda * \frac{T_{i}}{\rho}\right) * \ln \varepsilon}
$$

where:

$T_{s}$ : LST;

$T_{i}$ : the effective at-satellite brightness temperature in Kelvin;

$\lambda$ : wavelength of the emitted radiance ( $\lambda=11.5 \mu \mathrm{m}$ for Landsat band 6 data);

$\rho=\frac{h c}{\sigma}=1.438 \times 10^{-2} \mathrm{mk}$, where $h$ is the Plank's constant $\left(6.626 \times 10^{-34} \mathrm{Js}\right), c$ is the velocity of light (2.998

$\left.\times 10^{8} \mathrm{~m} / \mathrm{s}\right)$, and is the Boltzmann constant $\left(5.67 \times 10^{-8} \mathrm{Wm}^{-2} \cdot \mathrm{k}^{-4}=1.38 \times 10^{-23} \mathrm{~J} / \mathrm{k}\right)$;

$\varepsilon:$ is the land surface spectral emissivity.

\subsubsection{Normalizing LST}

Top-of-atmosphere (TOA) radiances, which are measured by satellite thermal infrared sensors, are the combination of three energy types. TOA includes the emitted radiance from Earth's surface, the upwelling radiance from the atmosphere, and the down welling radiance from the sky [26]. The differences between the TOA radiances, and land surface temperatures are influenced by atmospheric conditions. In the present study, despite the fact that the satellite images were selected during the same season, a normalization method was applied to avoid annual variation in atmospheric conditions [12]. This correction was performed by calculation of land surface spectral emissivity $(\varepsilon)$, which varied significantly due to differences in soil and vegetation cover characteristics [27]. Land surface spectral emissivity values were estimated from NDVI values [28], (Table 3).

NDVI was used to transform multispectral data into a single image band representing vegetation distribution [29]. NDVI values indicate the amount of green vegetation in a pixel. The standard algorithm was computed using ENVI 4.8 software, from the equation published in [30]. NDVI values range from -1 to +1 ; with higher values indicating more green vegetation. In highly vegetated areas, NDVI typically ranges from 0.1 to 0.6 , whereas urban surface and water values are negative. The normalization method used equation (3) to extract UHIs from LSTs (Table 4).

$$
U_{i}=\frac{T_{s}-T_{\min }}{T_{\max }-T_{\min }}
$$

where:

$U_{i}:$ UHI;

$T_{s}:$ LST;

$T_{\min }$ and $T_{\max }$ : minimum and maximum LST retrieved from all data, excluding extremes.

\section{Results and Discussion}

Unsupervised/supervised image classification procedures for Landsat Thematic Mapper data obtained during 1987-2012 were employed to generate detailed land use categories. Unsupervised classification classes were 
Table 3. NDVI values and its corresponding values of land surface spectral emissivity.

\begin{tabular}{cc}
\hline NDVI & Land surface spectral emissivity $\varepsilon$ \\
NDVI $<-0.185$ & 0.995 \\
$-0.185 \leq \mathrm{NDVI}<0.157$ & 0.970 \\
$0.157 \leq \mathrm{NDVI} \leq 0.727$ & $1.0094+0.047 \ln (\mathrm{NDVI})$ \\
$\mathrm{NDVI}>0.727$ & 0.990 \\
\hline
\end{tabular}

Table 4. Urban Heat Island (UHI) range and its classification.

\begin{tabular}{cc}
$\boldsymbol{U}_{\boldsymbol{i}}$ range & Class name and temperature range \\
$\left(0.0 \leq U_{i}<0.2\right)$ & Class 1: very law temperature \\
$\left(0.2 \leq U_{i}<0.4\right)$ & Class 2: law temperature \\
$\left(0.4 \leq U_{i}<0.6\right)$ & Class 3: moderate temperature \\
$\left(0.6 \leq U_{i}<0.8\right)$ & Class 4: high temperature \\
$\left(0.8 \leq U_{i} \leq 1.0\right)$ & Class 5: very high temperature \\
\hline
\end{tabular}

very similar to those produced in the supervised classification scheme.

Maximum likelihood supervised classification was applied to Landsat images acquired in 1987, 2000, and 2012 to assess land cover classes. Six land use categories were identified (Figure 2), including:

1) Surface water;

2) Quaternary playa deposits;

3) Fluviatile and lacustrine deposits;

4) Nile deposits and cultivated area;

5) Urbanized land; and

6) Miocene (gypsum and carbonate deposits).

Each class was checked and verified in the field using a Garmin 38 GPS unit, where more than 25 ground data sites were visited and examined. Results have shown that the urbanized areas have been increased from $49 \mathrm{~km}^{2}$ in 1987 to $57 \mathrm{~km}^{2}$ in 2012, whereas the areas of vegetation-cover have been expanded from $3.0 \mathrm{~km}^{2}$ in 1987 to $26 \mathrm{~km}^{2}$ in 2012.

[31] stated that with population growth, a consequent rise in urbanization takes place. This implies that the increasing building-rate in cities resulted in a noticeable reduction in green areas coupled with marked increase in impervious surfaces. [32] demonstrated that the excessive heat energy absorbed by an urban construction is large enough to raise the average temperature of urban areas by several degrees relative to surrounding nonurban areas.

In the present study, it was found that remote sensing technology was of adequate usage to monitor the impacts of urban growth and vegetation expansion on thermal environment in the North Gulf of Suez over the last 25 years. The thermal bands were processed to obtain radiant surface temperatures to investigate spatial and temporal effects of UHI associated with increasing urbanization and vegetation cover. Results have shown that the urban temperatures decreased from 1987 to 2012 (Figure 3). This can be explained in terms of the increasing role of the agricultural activities done over the last 25 years. During this period, many cultivated areas have replaced barren poor land. The UHI mitigation strategies, such as urban vegetation, play a remarkable role in cooling the urban environment. [33] have evidenced the significant role of vegetation cover in cooling effect, where the plants absorb much of the incoming solar radiation, and dissipate energy via transpiration rather than energy conversion to heat.

Efforts conducted to increase cultivated lands in urban environments help in reduction of surface temperature and cooling of the surrounding air.

Based upon the above findings, it is herein confirmed that the urban development and vegetation expansion are the major land cover changes that significantly impacted the thermal environment in the northern part of the Gulf of Suez during the last 25 years. 

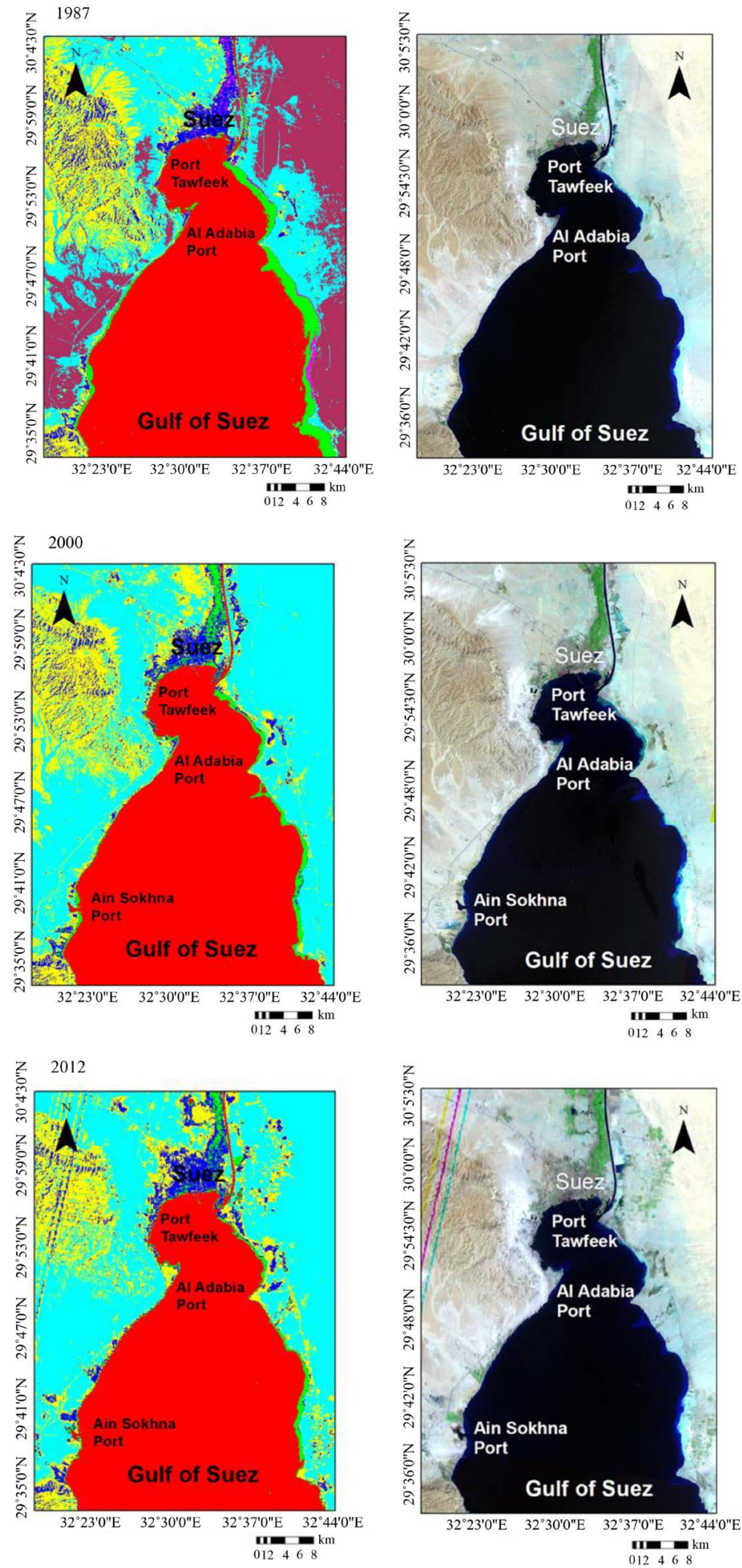

Surface Water

$\square$ Nile Deposits \& Cultivated area

Quaternary Playa Deposits

Urbanized Land

Miocene (Gypsum and Carbonate deposits)

Figure 2. Landuse/landcover changes during 1987-2012 in the North Gulf of Suez. 

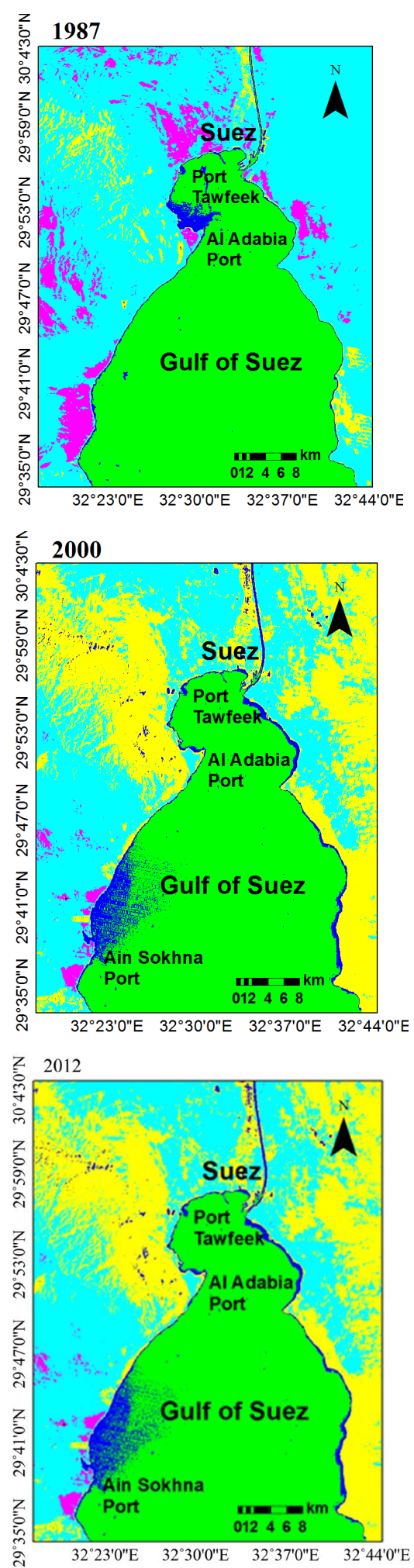

$\left(0 \leq \mathrm{U}_{\mathrm{i}}<0.2\right)$ Very law temperature

$\left(0.2 \leq \mathrm{U}_{\mathrm{i}}<0.4\right)$ Law temperature

$\left(0.8 \leq \mathrm{U}_{\mathrm{i}} \leq 1.0\right)$ Very high temperature $\left(0.4 \leq \mathrm{U}_{\mathrm{i}}<0.6\right)$ Moderate temperature

$\left(0.6 \leq \mathrm{U}_{\mathrm{i}}<0.8\right)$ High temperature

Figure 3. Urban heat island during 1987-2012 in the North Gulf of Suez. 


\section{Conclusions}

1) Three sets of Landsat Thematic Mapper images were used to classify land cover, and calculate UHIs in the northern part of the Gulf of Suez during 1987-2012.

2) Six land use classes were identified, including: surface water, quaternary playa deposits, fluviatile and lacustrine deposits, Nile deposits and cultivated area, urbanized land, and Miocene (gypsum and carbonate deposits).

3) Urbanized areas have been increased from $49 \mathrm{~km}^{2}$ in 1987 to $57 \mathrm{~km}^{2}$ in 2012, whereas the areas of vegetation-cover have been expanded from $3 \mathrm{~km}^{2}$ in 1987 to $26 \mathrm{~km}^{2}$ in 2012. Many barren lands are largely replaced by cultivated and vegetated ones.

4) Accordingly, the urban temperatures were directly decreased from 1987 (wide areas with very high and high temperatures) to 2012 (limited areas with moderate and low temperatures). Generally, moderate and low temperatures were progressively increased from 1987 to 2012.

5) The results of this study confirmed that urban development and vegetation expansion were the major land cover changes that significantly impacted the northern part of the Gulf of Suez thermal environment. The study has proved that despite the increased urban and industrial activities at the northern part of the Gulf of Suez, the thermal environment has experienced a decrease in values due to the expansion of cultivated/agricultural activities.

\section{References}

[1] Weng, Q. (2001) A Remote Sensing-GIS Evaluation of Urban Expansion and Its Impact on Surface Temperature in the Zhujiang Delta, China. International Journal of Remote Sensing, 22, 1999-2014.

[2] Voogt, J.A. and Oke, T.R. (1998) Effects of Urban Surface Geometry on Remotely-Sensed Surface Temperature. International Journal of Remote Sensing, 19, 895-920.

[3] Voogt, J.A. and Oke, T.R. (2003) Thermal Remote Sensing of Urban Climates. Remote Sensing of Environment, 86, 370-384. http://dx.doi.org/10.1016/S0034-4257(03)00079-8

[4] Yue, W.Z., Liu, Y., Fan, P.L., Ye, X.Y. and Wu, C.F. (2012) Assessing Spatial Pattern of Urban Thermal Environment in Shanghai, China. Stochastic Environmental Research and Risk Assessment, 26, 899-911. http://dx.doi.org/10.1007/s00477-012-0638-1

[5] Yue, W.Z. and Xu, J.H. (2008) Impact of Human Activities on Urban Thermal Environment in Shanghai. Acta Meteorologica Sinica, 63, 247-256.

[6] Kato, S. and Yamaguchi, Y. (2005) Analysis of Urban Heat-Island Effect Using ASTER and ETM Data: Separation of Anthropogenic Heat Discharge and Natural Heat Radiation from Sensible Heat Flux. Remote Sensing of Environment, 99, 44-54. http://dx.doi.org/10.1016/j.rse.2005.04.026

[7] Imhoff, M.L., Zhang, P., Wolfe, R.E. and Bounoua, L. (2010) Remote Sensing of the Urban Heat Island Effect across Biomes in the Continental USA. Remote Sensing of Environment, 114, 504-513. http://dx.doi.org/10.1016/j.rse.2009.10.008

[8] Huang, H., Ooka, R. and Kato, S. (2005) Urban Thermal Environment Measurements and Numerical Simulation for an Actual Complex Urban Area Covering a Large District Heating and Cooling System in Summer. Atmospheric Environment, 34, 6362-6375. http://dx.doi.org/10.1016/j.atmosenv.2005.07.018

[9] Hart, M. and Sailor, D. (2009) Quantifying the Influence of Land-Use and Surface Characteristics on Spatial Variability in the Urban Heat Island. Theoretical and Applied Climatology, 95, 397-406. http://dx.doi.org/10.1007/s00704-008-0017-5

[10] Sun, Q., Wu, Z. and Tan, J. (2012) The Relationship between Land Surface Temperature and Land Use/Land Cover in Guangzhou, China. Environmental Earth Sciences, 65, 1687-1694. http://dx.doi.org/10.1007/s12665-011-1145-2

[11] Weng, Q. (2012) Remote Sensing of Impervious Surfaces in the Urban Areas: Requirements, Methods and Trends. Remote Sensing of Environment, 117, 34-49. http://dx.doi.org/10.1016/j.rse.2011.02.030

[12] Xiong, Y., Huang, S., Chen, F., Ye, H., Wang, C. and Zhu, C. (2012) The Impacts of Rapid Urbanization on the Thermal Environment: A Remote Sensing Study of Guangzhou, South China. Remote Sensing, 4, 2033-2056. http://dx.doi.org/10.3390/rs4072033

[13] Li, J., Song, C., Cao, L., Zhu, F., Meng, X. and Wu, J. (2011) Impacts of Landscape Structure on Surface Urban Heat Islands: A Case Study of Shanghai, China. Remote Sensing of Environment, 115, 3249-3263. http://dx.doi.org/10.1016/j.rse.2011.07.008

[14] Said, R. (1962) The Geology of Egypt. Elsevier, Amsterdam. 
[15] Carlson, T.N., Gillies, R.R. and Schmugge, T.J. (1995) An Interpretation of Methodologies for Indirect Measurement of Soil Content Water. Agricultural and Forest Meteorology, 77, 191-205. http://dx.doi.org/10.1016/0168-1923(95)02261-U

[16] Eastman, J.R. (1997) Supervised Classification in IDRISI for Windows Version 2, Tutorial Exercises. Clark University, Worcester, 86-94.

[17] Lillesand, T.M. and Kiefer, R.W. (2000) Remote Sensing and Image Interpretation. John Wiley \& Sons, Inc., Hoboken, $650 \mathrm{p}$.

[18] Lillesand, T.M. and Kiefer, R.W. (1994) Remote Sensing and Image Interpretation. John Wiley \& Sons, Inc., Hoboken, $750 \mathrm{p}$.

[19] Lillesand, T.M., Kiefer, R.W. and Chipman, J.W. (2004) Remote Sensing and Image Interpretation. John Wiley \& Sons, Inc., Hoboken, 763 p.

[20] Mather, P.M. (1999) Computer Processing of Remotely-Sensing Images, an Introduction. 2nd Edition, John Wiley \& Sons, Inc., Chichester, 1-75.

[21] Salem, B.B., El-Cibahy, A. and El-Raey, M. (1995) Detection of Land Cover Classes in Agro-Ecosystems of Northern Egypt by Remote Sensing. International Journal of Remote Sensing, 16, 2581-2594. http://dx.doi.org/10.1080/01431169508954578

[22] Csillage, F. (1986) Comparison of Some Classification Methods on a Set Site (Kiskore, Hungary): Separability as a Measure of Accuracy. International Journal of Remote Sensing, 7, 1705-1714. http://dx.doi.org/10.1080/01431168608948962

[23] Hixon, M.M., Davis, B.J. and Bauer, M.E. (1981) Sampling Landsat Classification for Crop Area Estimation. Photogrammetric Engineering and Remote Sensing, 47, 1343-1348.

[24] Chander, G. and Markham, B. (2003) Revised Landsat-5 TM Radiometric Calibration Procedures and Post Calibration Dynamic Ranges. IEEE Transaction on Geosciences and Remote Sensing, 41, 2674-2677. http://dx.doi.org/10.1109/TGRS.2003.818464

[25] Wu, C., Wang, Q., Yang, Z. and Wang, W. (2007) Monitoring Heated Water Pollution of the DaYaWan Nuclear Power Plant Using TM Images. International Journal of Remote Sensing, 28, 885-890. http://dx.doi.org/10.1080/01431160600580616

[26] Van, T.T. and Bao, H.D.X. (2010) Study of the Impact of Urban Development on Surface Temperature Using Remote Sensing in Ho Chi Minh City, North Vietnam. Geographical Research, 48, 86-96. http://dx.doi.org/10.1111/j.1745-5871.2009.00607.x

[27] Van De Griend, A.A. and Owe, M. (1993) On the Relationship between Thermal Emissivity and the Normalized Difference Vegetation Index for Natural Surfaces. International Journal of Remote Sensing, 14, 1119-1131. http://dx.doi.org/10.1080/01431169308904400

[28] Liu, L. and Zhang, Y. (2011) Urban Heat Island Analysis Using the Landsat TM Data and ASTER Data: A Case Study in Hong Kong. Remote Sensing, 3, 1535-1552. http://dx.doi.org/10.3390/rs3071535

[29] Rouse, J.W., Haas, R.H., Schell, J.A. and Deering, D.W. (1974) Monitoring Vegetation Systems in the Great Plains with ERTS. Proceedings of 3rd Earth Resources Technology Satellite-1 Symposium, Greenbelt, NASA SP-351, 30103017.

[30] Jensen, J.R. (1986) Introductory Digital Image Processing. Prentice-Hall, New Jersey, 379.

[31] Ma, Y., Kuang, Y.Q. and Huang, N.S. (2010) Coupling Urbanization Analyses for Studying Urban Thermal Environment and Its Interplay with Biophysical Parameters Based on TM/ETM+ Imagery. International Journal of Applied Earth Observation and Geoinformation, 12, 110-118. http://dx.doi.org/10.1016/j.jag.2009.12.002

[32] Oke, T. (1987) Boundary Layer Climates. Routledge, New York.

[33] Owen, T.W., Carlson, T.N. and Gilles, R.R. (1998) An Assessment of Satellite Remotely Sensed Land Cover Parameters in Quantitatively Describing the Climatic Effect of Urbanization. International Journal of Remote Sensing, 19, 1663-1681. http://dx.doi.org/10.1080/014311698215171 